\title{
FATHOM
}

\section{Failed Capitalist and Father: Restored Order in Thomas Hardy's Mayor of Casterbridge}

Capitaliste et père déchus : l'ordre restauré dans The Mayor of Casterbridge

\section{Maria Granic}

\section{OpenEdition}

\section{Journals}

\section{Electronic version}

URL: http://journals.openedition.org/fathom/673

DOI: $10.4000 /$ fathom.673

ISSN: 2270-6798

\section{Publisher}

Association française sur les études sur Thomas Hardy

\section{Electronic reference}

Maria Granic, «Failed Capitalist and Father: Restored Order in Thomas Hardy's Mayor of Casterbridge », FATHOM [Online], 4 | 2016, Online since 15 October 2016, connection on 19 April 2019. URL : http:// journals.openedition.org/fathom/673; DOI : 10.4000/fathom.673

This text was automatically generated on 19 April 2019 


\title{
Failed Capitalist and Father: Restored Order in Thomas Hardy's Mayor of Casterbridge
}

Capitaliste et père déchus : l'ordre restauré dans The Mayor of Casterbridge

\author{
Maria Granic
}

1 "Character is Fate" (Hardy 2008, 107), says the narrator in Thomas Hardy's The Mayor of Casterbridge (1886), quoting Novalis. Through the words of the German Romantic writer, Hardy reveals his humanism, intimating that it is through the choices an individual makes rather than because of an external force that the individual determines his trajectory in a certain direction in life. While unpacking Novalis's claim, the novel depicts fate as an inner rather than an outer force and simultaneously reveals the narrator as a humanist and the protagonist as a human being animated by desires that, as we shall see, conflict, to a certain extent, with societal dictates. Thus, the novel represents an occasion not only for exegesis but also for a critical examination of the concept of the self, stimulating self-interpretation and self-evaluation. By citing Novalis's simple claim, the narrator deems the individual, and particularly the protagonist, Michael Henchard, responsible for his own failure as capitalist and father as well as for his exit from the society whose order he has disrupted. Here Hardy joins the seventeenth-century philosopher Baruch Spinoza, who had advanced the idea that we can understand an individual within a total structure. In Ethics, Demonstrated in Geometrical Order (1677), Spinoza had thought this total structure to be one substance, God, whose existence he found necessary, and to have universal laws, to which man is subject (ID6, Spinoza 1). Yet, as a humanist, Hardy diverges from Spinoza, supplanting the one substance with the social network of the communities in Weydon-Priors and Casterbridge, in Upper Wessex, where individuals have the power to make decisions regarding their fate. I propose that Henchard fails to develop qua individual and as a member of society because he considers the individual and the social facets of development to be separate and chooses his action as a response to his desire rather than his reason. Following, I will illustrate that at the heart of Henchard's choices lies his fear of death, materialized as desire, first to rise on 
the social scale and then to be the father, a fear that the narrative uncovers when Henchard faces the uncanny effigy representing him, floating down the river. He does not understand that being a husband and father implicitly and inextricably binds the private sphere with the social network. Nevertheless, his failure makes him appear as a human being who, trying to fulfil his desire, is subject to error, inviting thus the readers' sympathy. And although to err is human, erring does not appear as justification for Henchard's actions; it merely suggests the destructive potential that lies in the individual's choices when based solely on desire.

Before beginning an examination of the novel, a few more comments regarding my approach to the reading of Hardy's The Mayor of Casterbridge are in order. The following interpretation does not concern Hardy's view of humanism per se but rather his humanistic approach in the novel. Broadly viewed, the novel reveals several factors that prevent Henchard from developing successfully: his split view of the private and the social selves, mentioned above, his lack of concern for other individuals, and his selfinterest, the latter of which Spinoza viewed as a basic law of human nature. Henchard becomes an agent of disorder as a result of three key interconnected choices of actions rooted in an overpowering desire (and accompanying self-centeredness) rather than in reason. To wit, he chooses to auction his family while inebriated, to drink, and to lie (to the community, to Newson, and to Elizabeth Jane). Henchard's decisions result from his acting on the basis of his desire rather than on the basis of reason. Moreover, these are not the actions of a hero but those of a common individual.

Given the previous critics' analysis of Hardy's protagonists as tragic heroes in the Aristotelian sense and my emphasis on desire as a motor of action in Henchard's life, I will briefly consider desire from Aristotle's perspective. In De Anima (ca. 350 B.C.), Aristotle had shown that perception leads to desire, which in turn leads to action (2.3.1; Aristotle 1987, 53), and that even when reason urges action, the individual is still capable of acting in response to desire rather than on the basis of practical reason (3.9.8; 95). Through Henchard, Hardy dramatizes the fate of an individual whose desire overtakes reason and, as Spinoza would say, keeps him in bondage. Jeannette King has demonstrated that Hardy's protagonists are tragic heroes because they convince "through dialogue and action [...] rather than through analysis" (King 101). I would add a quotation from Aristotle's Poetics to claim that Henchard falls into adversity, "not through depravity, but through some kind of error" (Aristotle 1995, 13). And yet, I perceive Henchard as an unsuccessful or, to use a term applied to Victorian women, a fallen individual: he loses the respect of the community and falls not because he is a tragic hero but because he is a sad individual who does not reason but desires.

Desire is the mind's yearning, a form of energy channelled toward recognition and fulfilment. Whereas Spinoza defines desire as "the actual essence of man" (IIIP56, Spinoza page 100), Jacques Lacan describes it as the unconscious made conscious through its objects, the "objet a", which he terms signifiers of desire (Lacan 1977, 198). In the Lacanian schema, desire is ultimately of desire, the subject never being able to achieve it and instead moving along an endless chain of unfulfilling signifiers (Lacan 1981, 38). Henchard moves from a higher social status as a capitalist belonging to the middle-classes to the position of a husband and father. Jane Thomas has already established that Hardy's writings illustrate the role of desire in the conception of the self. Following J. Hillis Miller, Thomas sees desire to be generated by inaccessibility. Following Lacan, I consider desire to be present in the psyche from the end of the mirror stage onward. Developmentally, 
Henchard appears to be at the end of what Lacan terms the mirror stage, misidentifying with the figure of the capitalist, his Ideal-I ("The Mirror Stage", Lacan 1981, 2) and entering the symbolic order of language and, most importantly, of desire. In the symbolic order, where all human knowledge, Lacan claims, is mediated by desire (5-6), Henchard's knowledge is mediated by the "promising youth's high aims and hopes" (Hardy 2008, 9) to succeed in the fodder business as a "free man" (10), without the hindrance imposed by a wife and child. Now, a higher status seems to be a good and worthwhile goal, despite the sacrifice he is considering but upon which has not yet acted. He behaves as if overcome by what Plato terms lèthē in the Phaedrus, "forgetting" that gives rise to Henchard's illusion that the social facet is extricated from the private facet of individual development.

In other words, Henchard's social aspiration has two opposing forces which Plato attributes, in chapter 1 of The Republic (c. 380 B.C.), through Socrates, to the doctor, "the person who knows how to give protection from a disease who is also the expert at secretly inducing the disease" (I 333e, Plato 12). Henchard's social aspiration has therefore a similar function to that which Jacques Derrida refers to as pharmakon, a concept grounded in Plato's aforementioned double-edged idea. As Derrida says in Dissemination (1972), the pharmakon "acts both as remedy and poison, [...] can be alternatively or simultaneously - beneficent or maleficent" (Derrida 70). Desire is potentially transformative and motivates the individual but in Henchard's case, it is bound up with self-centeredness and leads to alienation. The novel offers a narrative of failed development resulting from self-centeredness, a development which, nonetheless, reveals Henchard as a human being. This is particularly so because he realizes his mistake when it is too late to be able to redeem himself. Hardy's principle aim in this novel is to illustrate not only the individual's choices in determining the course of his own life, but also the possible consequences resulting from these choices.

6 Henchard begins both the downward spiral of his failure as a husband and father but also the upward move as a self-made professional, by his auctioning of his family while intoxicated. Making choices under the guidance of his desire rather than of reason, he seeks his own advantage without considering the unintended consequences of his actions. According to Spinoza, pursuing what is useful to oneself can lead one toward perfection, but reason dictates that one should act so as to secure and further the order and harmony in society (IVP35, Spinoza132). As the novel intimates, Henchard's failure derives not from the primacy of self-interest, which for Spinoza is part of the individual makeup, but from his disregard for other individuals. Seeing himself trapped in a deadlock, as a poor young man with a wife and child and therefore no prospects, he desperately tries to find a way out but only for himself. Elaine Showalter has already pointed out that by selling his child, Henchard breaks the symbolic chain that connects him with his ancestors and offspring to enter society as "the new Adam, reborn, self-created, unencumbered" (Showalter 57). This new Adam, I contend, believes he is a social individual, striving to become a capitalist, his Ideal-I, the phantom which is born out of his desire and, as I will illustrate, his fear of death, and dominates him most of his life. I concur with Annie Ramel, who maintains that Henchard fails because he is "a flawed and parodic fatherfigure" (Ramel 266). This failed father operates in a social realm in which he auctions his family, an act which Bruce Johnson astutely describes as Henchard's passageway to a new paradigm: "The wife auction as a symbol is ... a complex revelation of Henchard's passing from the roughly georgic and pastoral world to the world of mayors and towns and 
business" (Johnson 80). Under the influence of alcohol, which cancels his capacity to reason, Henchard believes that the ends justify the means and that by repressing his individual development, he is creating the circumstance necessary for his social development as a middle-class man.

The auctioning scene, a locus classicus of criticism, shows Henchard's self-centeredness when, uninhibited by alcohol, brings about his crisis. In his analysis of the novel, Steven Earnshaw remarks that "Henchard's drunkenness leads to the break-up of the family unit, literally, when he sells his wife at a fair after too much to drink" (Earnshaw 147-148), yet concludes that the novel "refuses to allow drink to be the scapegoat for all society's troubles as many avowed" (152-153). As the narrative unfolds, "the drink problem" gains a more complex shape than the either/or middle-class worldview which Henchard, in common with his age, holds, and which Earnshaw expresses as follows: "Drink and you will suffer disease, poverty, violence, insanity, waste and death; give up drink and you will live in domestic bliss and affluence" (145). Although Henchard considers drinking to be the root of his problem, the novel suggests that it is his desire to pursue his imago that leads to his separation from his family and brings about his later fall. The rum-spiced furmity exacerbates Henchard's self-centered desire to the point that it reduces everything to his desire to advance socially; hence, he decides that he has no use for his wife, so he queries: "Who'll have her?" (Hardy 2008, 11), and then insistently asks: "Will anybody buy her?" (11). Bernard J. Paris considers Henchard to be "angry with himself, his wife, and fate for thwarting his search for glory" (Paris 57). The rum cancels Henchard's locus of control, his desire overpowering his reason and revealing him as a man who has no affection for his wife and daughter. It is because of this lack that Henchard sets his wife and daughter's exchange value, much as "these gipsy fellows do their old horses" (Hardy 2008, 10), at five guineas (12-13). Henchard's act of ridding himself of his family does not inspire a strong negative reaction on the part of the lower classes, since some of the guests confirm the practice among some people: "There's them that would do that" (10).

The thought of money brings the rum-infused Henchard an irrational optimism about his future and the illusion of being able to control his life. Yet, blinded by desire and having no consideration for others, he fractures his individual development: he rejects fatherhood so as to seek social advancement through the acquisition of wealth and respectability. In so doing, he perturbs the sanctioned Victorian order while following a signifier that is not able to satisfy him at the ontological level. Because the inebriated Henchard has no emotions concerning his wife and daughter, he does not experience cognitive dissonance, a mental phenomenon whereby he would ensure that his beliefs and behaviours coexist harmoniously. Nonetheless, his social aspiration, a remedy for his poverty in his view, becomes a poison for him both as a family man and as a social individual.

Under the influence of this poison, Henchard not only values his family's worth in money but also devalues the human worth of the two individuals, disturbing the normal function of the family and of society. Having decided to commit himself to materialistic pursuits that will bring him public recognition, he shows no recognition of the vanitas in such a pursuit at the cost of his family life. He foreshadows a character developed four years later, by Oscar Wilde in his only novel, The Picture of Dorian Gray (1890). Dorian Gray "suffers" from the same conditions which have afflicted Henchard, namely, desire, narcissism and a split view of the self, but the former's development follows a different 
path. Unlike Henchard, Dorian privileges his individual self-fashioning and Lord Henry's idea of New Hedonism, rejecting social interaction. Through Henchard, Hardy's narrative "about deficient fatherhood and the disasters that result from it", as Ramel describes it (Ramel 259), exemplifies the narcissistic nature of desire and the split subject's failure to achieve satisfaction, but not of an evil individual, as in Wilde's novel. More importantly, it portrays Henchard as an agent of disorder who pursues his selfish desire by taking the capitalist idea that possessions such as a wife and a child represent money and can be exchanged ad absurdum.

10 In the morning, when Henchard is sober and reason inhibits desire, he half admits the folly of the auctioning but desire wins: he places the responsibility of the event onto Susan, exclaiming in frustration: "Yet she knows I am not in my senses when I do that!" (Hardy 2008, 17). He regards, as Paris argues, the selling of his wife and daughter as immoral when he is sober (Paris 57). Nevertheless, I would emphasize, he does not assume responsibility for his action and instead casts blame on Susan, who due to the "simplicity of her intellect" (Hardy 2008, 17) took his words literally: "Tis like Susan to take such idiotic simplicity" (18). In other words, she did not recognize that he was ruled by desire. Neither did she comprehend his desire to succeed in moving up the social ladder since she does not have any such aspirations. Eschewing personal responsibility, he considers Susan to be a destabilizing agent: "Meek - that meekness has done me more harm than the bitterest temper!" (18). His thoughts reveal his fear of public shame but not of the private shame, since he does not value Susan much as an individual.

Through the disorder he creates in his personal environment, Henchard also destabilizes the larger environment: he denigrates the importance of the institution of marriage sanctioned by the Victorian middle class. Breaking himself off from the domestic sphere, he intends to inhabit only the social sphere of class mobility. However, for the Victorians, the family, the basic unit of society, is under the authority of the paterfamilias - husband, father, and master, who is physically absent from the unit to practice his profession in the market place but returns to it and supports it. Scholars of Victorian culture such as Leonore Davidoff and Catherine Hall as well as John Seed have shown that family is a central institution of middle-class life. Whereas Henchard aspires to climb the social ladder, he causes the disintegration of his family, which in his view lies outside institutional boundaries, auctioning its other members as if they are useless "articles" (Hardy 2008, 10), as he calls his them. Rationalizing his action, he finds reassurance in the fact that such practice is not new among men: "It has been done elsewhere - and why not here?" (13). By law, the Victorian woman gave up her name, identity, right to her own body, and legal existence through marriage. Therefore, Henchard legally owns Susan and their daughter. As an owner, he has the right to sell his property. Yet, in so doing he not only disregards the institution of marriage but also deprives himself of his wife's help. As John R. Gillis contends, Victorian husbands could work in the marketplace, an amoral place, provided that they "could be rescued by women's moral vigilance at home" (Gillis 74). Without Susan, Henchard may pursue his desire to ascend the social scale, but does not receive the help necessary for him to achieve the individual and spiritual wellbeing he needs in to perform well in the marketplace.

The reader can only surmise Henchard's strict self-discipline and ascetic life in the nineteen years which the narrative does not cover and during which he has become the Mayor of Casterbridge. The significance of the title lies in the fact that it specifies a person of a special sort, a mayor, that is, a leader belonging to a higher class, a man who 
works for the benefit of and on behalf of others and who represents the views of a group or class. To have gained his social status, however, Henchard followed his desire, associated with femininity rather than with masculinity. In the Victorian ideas of masculine self-fashioning expressed by Thomas Carlyle ("Past and Present" and "Shooting Niagara: And After?")', and Samuel Smiles (Self-Help), among others, selfdiscipline and asceticism play a chief role ${ }^{2}$. This ascetic self-fashioning occurred during the explosive development of industry acclaimed by Carlyle, for example, who saw the "Captains of Industry" as "Fighters against Chaos, Necessity and the Devils of Jötuns" (Carlyle 163), and during the discussions engendered by the Darwinian Theory. As a result of such discussions, the Christian God, whose representative in the family is the father, became decentred by money. Sigmund Freud contends that one of the effects of civilization, which we can apply to industrialization and its impact on the Victorians, is that men withdraw from women, constantly associating with men and thus removing themselves from their duties as husbands and fathers (Freud 1962, 50-51). Thus, we can suggest, with Freud, that a crisis of Victorian masculinity and consequently of paternity emerges in Hardy's novel through Henchard.

The shift to an economic and ideological middle-class development experienced by an increasing number of individuals results in the focus on the problems of assessing one's value and of finding one's place in society. Often times, the problem is not how society perceives individuals but how they perceive themselves when they assume the patriarchal, hegemonic, middle-class viewpoint, according to which they do not have the values that make this class "the moral heart of Victorian society" (Altick 29). Therefore, by accepting the viewpoint that ousts them from the middle-class, some characters doom themselves to failure; they place themselves in a dilemmatic position in that, because they do not possess middle-class values, they cannot become a part of a middle class community. For characters who aspire to attain value within the middle-class have to prove that they live according to the values of this class - domestic and public virtues such as chastity, work ethics, cleanliness, religiosity, which in turn enforce the Victorian middle-class norms. According to these norms, Earnshaw contends, drink is "a distinctly class issue" (Earnshaw 144); it is an activity of the poor class. And Henchard gives up drinking on account of his desire to move up the social scale.

Henchard makes an attempt to achieve a level of order and harmony as dictated by his desire. He appears as though he is making a pact. Critics have interpreted Henchard's act of giving up drinking as a sign of repentance (Earnshaw 148), and alternatively, as a form of self-punishment (Paris 57). Yet the free indirect discourse through which the narrator conveys the protagonist's thoughts does not indicate either repentance or selfpunishment; rather, it expresses his decision to tolerate Susan's reaction without complaint: "When he was calmer, he turned to his original conviction that he must somehow find her and his little Elizabeth-Jane, and put up with the shame as best as he could" (Hardy 2008, 18). Abstinence constitutes a necessary change that allows Henchard to dedicate his energy to his work and social advancement. In a short, melodramatic scene, he determines that before finding and facing Susan he must take an official oath, in his words, to "register an oath" (18), which has to be "a greater oath than he had ever sworn before" (18), given, we may surmise, the seriousness of his deed. For this, he needs the necessary props: "To do it properly he required a fit place and imagery" (18). On his knees and with his head on the Bible, he swears to give up drinking not for good but for 
twenty-one years, the number reflecting his age. After the oath he has a sense of relief "at having made a start in the right direction" (18).

His attempt to restore his family unit is too feeble, his goal being to protect his reputation by keeping the truth about his conduct from surfacing. And he does so not out of love for himself, which Spinoza associates with reason (IVP18, Spinoza 125), but rather out of repugnance for himself. The narrator's commentary is revealing:

The truth was that a certain shyness of revealing his conduct prevented Michael Henchard from following up the investigation with the loud hue-and-cry such a pursuit demanded to render it effectual; and it was probably for this reason that he obtained no clue, though everything was done by him that did not involve an explanation of the circumstances under which he had lost her. (Hardy 2008, 19)

When he understands that his family may have emigrated with Richard Newson, the sailor who had bought them, he stops the search, choosing to further his social development. About two decades later, the prosperous hay-trusser/mayor is an esteemed middle-class man with financial acumen and a solid work ethic. Despite the fact that Henchard is not the exceptional hero depicted by Aristotle in his Poetics (c. 335 B.C.), he is brought face to face, as King would say, "with the past he tried to escape" (King 97): Susan and her daughter have come to Casterbridge.

The Ring of Casterbridge, a Roman amphitheater where Henchard meets Susan, does not enable his introspection. This space calls to mind, significantly, both the fall of an empire and the shape of a ring, the latter being symbolic of union through marriage. As a vestige of the past, the Ring, a remnant of what the past was, suggests the transience of great individuals and their achievement through its 'presence'. Also, as a memento, it intimates the importance of the past for the present. The vestige overturns the idea of progress, an idea with which the Victorians struggled to come to terms but which Henchard overlooks. Compared to the rise and fall of the Roman Empire, Henchard's rise and fall later in the novel appear derisory; nonetheless, his is the fall of a human being who becomes aware of his mistakes too late. This "huge circular enclosure" (Hardy 2008, 67), as the narrator describes it, does not make Henchard feel threatened despite the fact that it represents a place of "intrigues" (67) rather than a place "of happy lovers" (68).

Henchard feels compelled to marry Susan again not out of affection for her but out of fear of public shame if people found out what he had done in his youth. He seems to recognize his having auctioned his wife and daughter as an act that deems him unfit to lead and serve the community as mayor. That is why, his first utterance in Susan's presence is to reassure her that he has given up drinking, which in his view lay at the heart of his problem: “I don't drink' (Hardy 2008, 69). In the place of secrecy, Henchard succinctly lays out his plan to further his secret, that is, to lie to the community he is leading: "I meet you, court you, and marry you, Elizabeth-Jane coming to my house as my stepdaughter. The thing is so natural and easy that it is half done in thinking o't. This would leave my shady, headstrong, disgraceful life as young man absolutely unopened; the secret would be yours and mine only" (70). As the novel unfolds, Henchard's past, to which he alludes in the enclosure of the Ring, gains meaning for the present, moving outside the Ring: the secret inside the marriage (symbolized by the ring) goes outside, into the community. The reality of the Ring calls for the Casterbridge individuals to look into the abyss and face death, to learn from their mistakes rather than to perpetuate them. Yet, Henchard appears to be oblivious to the imminence of death. However, he has a different attitude towards Susan, whom he treats as a worthy individual capable of reasoning - he allows her to propose another plan: "If you can hit upon a better one we'll adopt it" (70). 
Furthermore, he asks her for forgiveness and when she hesitates to give him an answer, he sounds convinced that he will make up for past mistakes, asking her to judge him by "his future acts" (71). Because desire is of desire, social success, a mere objet $a$, does not fulfill Henchard's desire.

Having realized the limited benefits of social success, now Henchard shifts his desire; he intends to reorder his priorities and alter the direction of his life by re-fashioning himself at an individual level. He wants to acquire the position that he had rejected in his youth, i.e., that of the father. Yet, he does not understand what fatherhood entails. From a Darwinian standpoint, fathering ensures the survival of the bloodline through offspring. As John Tosh has noticed, the father has sons who carry forward his name and lineage (Tosh 4). In his capacity of father and husband, the man is tied to the domestic sphere. Claudia Nelson examines men's domestic invisibility, challenging Davidoff and Hall's claim concerning the father's contribution to his children's education, careers, and marriage. In Nelson's view, at this time families were undergoing change, men being increasingly identified with their position in the marketplace rather than their home (Nelson 3). The depiction of fatherhood in Victorian novels reveals Victorian anxieties concerning the future of the family, its abating cohesiveness. Henchard wants Newson's daughter, whom he mistakes for his offspring, to take his last name and tells her that he had named her Elizabeth-Jane: "'Twas I that chose your name, my daughter; your mother wanted it Susan" (Hardy 2008, 115). Thus, he arrogates the right of the father to name his child.

When his fortune declines, after the bidding he hired Jopp to conduct against Donald Farfrae, Henchard needs Elizabeth-Jane's affection and wants to strengthen the bond between him and her. This type of non-biological paternal bond was established in fiction, mutatis mutandis, by Charles Dickens in Great Expectations (1860) over two-and-ahalf decades before the publication of The Mayor of Casterbridge. While Abel Magwitch dedicates himself selflessly to his adopted son, Pip, and helps him to become a gentleman, Henchard merely uses Elizabeth-Jane for his benefit. As Paris contends, she is for him "both a source of affection and a means of restoring his pride" (Paris 62), as well as a means "to suppress his aggressive tendencies" (63). Being aware of how significant her presence has become for him, Henchard goes to great lengths to keep her in his life, including lying. Since he lacks empathy, his fashioning as a father is guided, as his fashioning as a capitalist had been, by selfish desire. He persists in his selfishness even after he sees the effigy.

The effigy floating in the water representing Henchard jolts him into consciousness, revealing his fear of death. This ghostly object is an example of the uncanny (or Unheimlich), theorized by Sigmund Freud in his 1919 analysis of E. T. A. Hoffmann's Gothic tale "The Sandman" (1817). In The Uncanny (1919), Freud depicts the uncanny as the deeply familiar desire or fear materializing into something fearful and frightening. Whereas at the beginning of the novel Henchard fears the deadlock in which he finds himself, toward the end he is afraid of death. The floating effigy is a fitting representation of Henchard's fall and a way to foreshadow his death. Unlike the vestiges, the effigy horrifies Henchard, uncovering what is familiar, i.e., his fear of death, which once took the estranged form of social failure and has now returned to its original meaning:

In the circular current imparted by the central flow the form was brought forward, till it passed under his eyes; and then he perceived with a sense of horror that it was himself. Not a man somewhat resembling him, but one in all respects his 
counterpart, his actual double, was floating as if dead in Ten-Hatches-Hole. (Hardy

2008, 276)

Now, Henchard sees himself as others see him and becomes aware of his alienation.

Referring to 0 . Rank's work, Freud reminds his reader of the former's link between mirror-images and the fear of death (Freud 2003, 142). As a mirror-image, the effigy becomes what Freud would call "the uncanny harbinger of death" (142), foreshadowing Henchard's demise. Confronted with the imminence of his death, Henchard refuses to reveal the truth to Elisabeth-Jane but when she volunteers to help him, unaware of his lies to her biological father, he asks her, incredulously: "How will you forgive all my roughness in former days?" (Hardy 2008, 278). He persists in his ways, refusing to reveal his secret.

21 The only change that Henchard has made is that now he is sacrificing his social fashioning to focus on his individual fashioning, still not recognizing the imbrication of these two facets. To ensure that he continues to play the paternal role, he lies to Elizabeth-Jane's biological father, telling him, "without hesitation" (Hardy 2008, 272), that she is dead. Family relationships require sacrifice, the reverse of what Henchard has been doing. Sacrifice, combined with truth, has the potential to increase trust and to strengthen the connection between people. Henchard's mimetic desire obscures his reason, so he wants "a greedy exclusiveness in relation to her" (273). By trying to keep his non-biological family together, he threatens to keep another family apart. He has become prey to his own egotism and feels no compassion for Newson: "His grief - what was it, after all, to that which he, Henchard, would feel at the loss of her" (273). Above all, he does not take into account Elizabeth-Jane's right to be reunited with her real father, acting as an agent of disorder. He surprises her by taking "her hand with anxious proprietorship" (274), a gesture which she takes for affection. However, the narrator clarifies that Henchard's is not the selfless attitude of a father but instead the attitude of an egoist: "The sympathy of the girl seemed necessary to his very existence" (279-280). That is why he does not reveal to her the truth - that her father is alive, although he intuits that she would soon discover it, preferring to live in the moment and keep the illusion of the familial bond.

Henchard is not willing to sacrifice his pride for the right motive. He justifies his lie to himself by claiming that it was not the result of reason but of intense emotion: "To satisfy his conscience somewhat, Henchard repeated to himself that the lie which had retained for him the coveted treasure had not been deliberately told to that end, but had come from him as the last defiant word of a despair which took no thought of consequences" (Hardy 2008, 280). His egotism goes as far as to distress Elizabeth-Jane by telling her that he is to leave Casterbridge, withholding the information that her real father is looking for her. His gesture is a sacrificial act for the wrong reason. Henchard does intend to ask her for forgiveness after she is reunited with her father, but when he faces her and hears her reproach, his pride stands in the way. For him, pride is a protective shield against suffering, but in fact, it holds him back from establishing a connection with ElizabethJane, possibly with Newton, as it had prevented him from connecting with Farfrae. His reputation takes precedence over honesty, the basis of a healthy relationship. He avoids honesty not out of a desire to be a good adoptive father but to avoid conflict. In his view, his lies and withholding the fact that Susan had lied to him about Elizabeth-Jane, represent desperate attempts to maintain the girl's love for him; they are "last desperate throw of a gamester who loved her affection better than his own honour" (303). That is 
why, he does not re-initiate the relationship, giving up without thinking through his role in Elizabeth-Jane's life. He becomes withdrawn and asks her to forgive him not for having lied but for bothering her on her wedding day. In his youth, Henchard had devalued the worth of his family; now, the narrator asserts, Henchard devalues his own worth: "He did not sufficiently value himself to lessen his sufferings by strenuous appeal or elaborate argument" (303). He has given up. Therefore, he promises Elizabeth-Jane not to bother her ever again, ending his speech proudly with a simple "Good-bye!" (303), cutting of contact. Even in the last moments of his life Henchard is guided by emotions, using his will as a tool to protect himself post mortem by foregrounding, once more, his selfcenteredness. Similarly to Gwendolen Harleth in George Eliot's Daniel Deronda, he chooses to lose triumphantly if he cannot win triumphantly, to remain in control even after his death.

23 A concern with the fate of the father and the family in a changing society underlies Hardy's Mayor of Casterbridge. Henchard's story depicts the development of a man led by emotions and believing that the individual and the social self-fashioning are two separate aspects of human life. Hence, he follows one at the expense at the other, refusing to see their symbiotic relationship. By teaching its readers that the individual and the social selves have an organic existence, the novel also illustrates how one's choices in either sphere affects one's path in life. Henchard's desire-driven choices mask his fear of death, which first he supplants with the fear of social failure. His fear increases and returns to its original form when he sees the uncanny figure of the effigy. Because Henchard follows his desire and refuses to reason, he believes that he can either make his way up the social scale outside fatherhood or try to be a father by disregarding middle-class mores. First, he attempts to gain social ascendance while giving up his roles and responsibilities as a father and husband, two roles which inscribe individuals both in the private and in the social sphere. Because he does not reason, he does not understand that the family unit represents a microcosm which entails a macrocosm, that of society as a whole, and that by disrupting the order within his family, Henchard disrupts societal order. After he reunites with Susan, he supports her financially, but the novel offers no indication that he receives spiritual strength from her. Then, although the vestiges do not increase his awareness and do not enable his reasoning, Henchard reconfigures his desire and pursues the role of the father. He acts like this only to use his right to provide for and name his daughter. Yet, his focus on his desire in the private realm at the expense of his social position results in his withdrawal from society. Since Henchard is not ready to be a middle-class father, he cannot remain either as mayor or as Elizabeth-Jane's father in Casterbridge. He has become alienated from both the private and the social sphere, functioning as an agent of disorder in both, the narrative supplanting him with his will. His death away from everyone, at the cottage of Abel Whittle, represents not only a selfremoval from the social and personal sphere but also a restoration of the order which he had disturbed in the first place. His character is his fate, but his fate is not the fate of the society. 


\section{BIBLIOGRAPHY}

Adams, James Eli, Dandies and Desert Saints: Styles of Victorian Manhood, Ithaca: Cornell UP, 1995.

Altick, Richard D., Victorian People and Ideas: A Companion to the Modern Reader of Victorian Literature, New York: W. W. Norton, 1973.

Aristotle, De Anima (c. 350 B.C.), transl. Mark Shiffman, Newburyport: Focus Publishing, 2011.

Aristotle, Poetics (335 B.C.), transl. Stephen Halliwell, Cambridge: Harvard UP, 1995.

Carlyle, Thomas, "Past and Present", Prose of the Victorian Period, ed. William E. Buckler, Boston: Houghton Mifflin, 1958, 129-167.

Davidoff, Leonore and Catherine Hall, Family Fortunes: Men and Women of the English Middle Class, 1780-1850, London: Routledge, 2002.

Derrida, Jacques, Dissemination (1972), transl. Barbara Johnson, Chicago: Chicago UP, 1981.

Earnshaw, Steven. “The Reason for Drinking in Hardy's The Mayor of Casterbridge”, Varieties of Victorianism: The Uses of a Past, ed. Gary Day, London: Macmillan, 1998, 142-160.

Freud, Sigmund, Civilization and Its Discontents (1930), transl. \& ed. James Strachey, New York: W. W. Norton, 1962.

Freud, Sigmund, The Uncanny (1919), ed. David McLintock, New York: Penguin Classics, 2003. Gillis, John R., For Better, for Worse: British Marriages, 1600 to the Present, New York: Oxford UP, 1985. Hardy, Thomas, The Mayor of Casterbridge (1886), ed. Dale Kramer, Oxford: Oxford UP, 2008. Johnson, Bruce, "The Mayor of Casterbridge and The Woodlanders", True Correspondence: A Phenomenology of Thomas Hardy's Novels, Tallahassee: UP of Florida, 1983, 76-94.

King, Jeannette, Tragedy in the Victorian Novel: Theory and Practice in the Novels of George Eliot, Thomas Hardy and Henry James, Cambridge: Cambridge UP, 1978.

Lacan, Jacques, Écrits: A Selection (1966), transl. Alan Sheridan, London: Tavistock, 1977.

Lacan, Jacques, The Four Fundamental Concepts of Psychoanalysis (1973), ed. Jacques-Alain Miller, transl. Alan Sheridan. New York: W. W. Norton, 1981.

Miller, J. Hillis, Thomas Hardy, Distance and Desire, Cambridge: Harvard UP, 1970.

Nelson, Claudia, Invisible Men: Fatherhood in Victorian Periodicals, 1850-1910, Athens: U of Georgia P, 2010.

Paris, Bernard J. "The Mayor of Casterbridge”, A General Drama of Pain: Character and Fate in Hardy's Major Novels, New Brunswick: Transaction Publishers, 2012, 55-80.

Plato, The Republic (c. 380 B.C.), transl. Robin Waterfield, Oxford: Oxford UP, 1993.

Ramel, Annie. "The Crevice in the Canvas: A Study of 'The Mayor of Casterbridge”, Victorian Literature and Culture, 26.2 (1998): 259-272.

Seed, John, "From 'Middling Sort' to Middle Class in Late Eighteenth- and Early NineteenthCentury England", Social Orders and Social Classes in Europe since 1500: Studies in Social Stratification, ed. M. L. Bush, London: Longman, 1992, 114-135. 
Showalter, Elaine, "The Unmanning of the Mayor of Casterbridge", Thomas Hardy's The Mayor of Casterbridge, ed. Harold Bloom, New York: Modern Critical Interpretations, 1987, 53-68.

Spinoza, Benedict de, Ethics, Demonstrated in Geometrical Order (1677), ed. \& transl. Edwin Curley, London: Penguin Books, 1996.

Thomas, Jane, Thomas Hardy and Desire: Conceptions of the Self, London: Palgrave Macmillan, 2013.

Tosh, John, A Man's Place: Masculinity and the Middle-Class Home in Victorian England, New Haven: Yale UP, 2007.

\section{NOTES}

1. In Past and Present and in Shooting Niagara: And After? Carlyle describes the Captains of Industry and the developing Industrial Hero, respectively as middle-class, disciplined and dignified men who will "recivilize" the world of industry (Carlyle).

2. In Dandies and the Desert Saints, James Eli Adams views asceticism as an important element in the middle-class writer's self-fashioning (Adams).

\section{ABSTRACTS}

Thomas Hardy's novel The Mayor of Casterbridge (1886) presents the author as a humanist and the protagonist, Michael Henchard, as a human being who follows his desire. My claim is that Henchard fails as a capitalist and as a father because he perceives the personal and the social aspects of individual developmental to be split rather than in a symbiotic relationship. He does not understand that being a husband and father implicitly and inextricably binds the private sphere with the social network. Henchard becomes an agent of disorder as a result of three key interconnected choices of actions rooted in an overpowering desire: he auctions his family, drinks, and lies. While following his desire, Henchard favors the social aspect of his development at the cost of the personal one, fractures his development, and perturbs the sanctioned Victorian order. He fails because desire, in the Lacanian schema, is of desire and is never fulfilled. First, Henchard rejects fatherhood, choosing to rise up the social ladder through acquisition of wealth and respectability. Developmentally, he is at the end of what Jacques Lacan terms the mirror stage, identifying with the figure of the capitalist, his Ideal-I, entering the symbolic order of language and desire. Lacking compassion and the sacrificial spirit of a father, he auctions his family, whom he perceives as an impediment. Later, the esteemed middle-class man with financial acumen and work ethics reconfigures his desire, taking on the paternal role, but becomes socially alienated.

Le roman Le Maire de Casterbridge de Thomas Hardy présente l'auteur comme un humaniste et le protagoniste, Michael Henchard, comme un être humain qui poursuit l'accomplissement de son désir. Le titre de cet article souligne que Henchard échoue en tant que capitaliste et en tant que père parce qu'il perçoit son développement individuel dans ses aspects personnel et social de façon séparée, et non comme agissant en symbiose. Il ne comprend pas que le fait d'être mari et père associe implicitement et intrinsèquement la sphère privée à la sphère sociale. Henchard 
devient un agent du désordre suite à trois choix interconnectés et ancrés dans un même désir de maîtrise : il vend sa famille aux enchères, boit et ment. En cherchant à accomplir son désir, Henchard favorise l'aspect social de son développement aux dépens de l'aspect personnel ; il fracture son développement et trouble l'ordre établi victorien. Il échoue parce que le désir, selon les termes de Lacan, est désir du désir qui n'est jamais accompli. D'une part, Henchard rejette son rôle de père et choisit de s'élever socialement en acquérant la richesse et la respectabilité. D'un point de vue développemental, il se situe au terme de ce que Lacan appelle le stade du miroir, s'identifiant avec la figure du capitaliste, son Idéal-I ("Le Stade du miroir" 2) et pénétrant dans l'ordre symbolique du langage et du désir. Manquant de compassion et de l'esprit sacrificiel d'un père, il met aux enchères sa famille qu'il perçoit comme un obstacle. D'autre part, l'homme de la classe moyenne, qui a le sens des affaires et obéit à une éthique du travail reconfigure son désir et se substitue au rôle parental, mais le rend socialement aliéné.

\section{INDEX}

Keywords: humanity, humanism, desire, individual development, social development, disorder, choice

Mots-clés: humanité, humanisme, désir, développement individuel, développement social, désordre, choix

\section{AUTHOR}

\section{MARIA GRANIC}

Maria Granic is an Assistant Professor of English Literature and Language at Benedictine University at Mesa (Arizona). Her research interests include the concepts of the ludic drive and of the father, theatricality in Victorian literature and culture, the New Woman and the New Man in late-Victorian literature, and literary theory. Among her pedagogical interests figure: orphans in literature, representations of agents of change in literature, and the Victorian novel. 